\title{
Antioxidant activity, total phenolic, and aflatoxin contamination in tempeh made from assorted soybeans (Glycine max L Merill)
}

\author{
*Yudiono, K., Ayu, W.C. and Susilowati, S. \\ Department of Food Technology, Faculty of Agriculture, Widya Karya Catholic University, Malang 65115, \\ East Java, Indonesia
}

\begin{abstract}
Article history:
Received: 11 November 2020

Received in revised form: 18

December 2020

Accepted: 22 February 2021

Available Online: 27 June

2021
\end{abstract}

Keywords:

Aflatoxin,

Antioxidant,

Phenolic compound,

Tempeh,

Soybean types

DOI:

https://doi.org/10.26656/fr.2017.5(3).655

\begin{abstract}
Tempeh is a fermented product made from soybeans or other types of legumes using Rhizopus oligosporus and Rhizopus oryzae moulds. Soybean contains phenolic compounds. Phenolic compounds found in soybeans partially act as an antioxidant. Antioxidants are components that are able to inhibit the oxidation process. Soybean also contains aflatoxins. Tempeh made from fermented soybeans may indicate to contain aflatoxins. This study used a Completely Randomized Design (CRD) with treatments of four soybean types, namely imported "Bola" brand soybean $\left(A_{1}\right)$, local Dena 1 type soybean $\left(A_{2}\right)$, local Devon 1 type soybean $\left(A_{3}\right)$, and local Anjasmara type soybean $\left(A_{4}\right)$. Each treatment was repeated three times. Analyses carried out include antioxidant activity, total phenolic compounds and aflatoxin contamination. The results of antioxidant activity analysis show that the highest activity is found in Anjasmara tempeh at $38.62 \pm 0.22 \%$ and the lowest in Dena 1 tempeh at $29.83 \pm 0.12 \%$. The results of the total phenolic analysis showed that the highest activity is found in Anjasmara tempeh at $16.26 \pm 0.29 \mathrm{mg} \mathrm{GAE} / \mathrm{g}$ extract and the lowest in Dena 1 tempeh at $13.96 \pm 0.29 \mathrm{mg} \mathrm{GAE} / \mathrm{g}$ extract. The results of aflatoxin analysis, using the LC-MS/MS method confirmed that tempeh raw materials (USA-imported, Dena 1, and Anjasmara) contain aflatoxin of B1, B2 and G1 types, while Devon 1 material was confirmed to contain B1 and B2 types. The lowest aflatoxin concentration is found in tempeh made from Devon 1 at $2.53 \times 10^{-7} \mathrm{ppb}$ of the $\mathrm{B}_{2}$ aflatoxin type.
\end{abstract}

\section{Introduction}

Soybean variety is one of the key components in developing the quality of soy-based processing, for example, tempeh. Tempeh is a fermented product made from soybeans, in addition to being a source of protein, tempeh is also rich in essential substances such as fibre, vitamin $\mathrm{B}, \mathrm{Ca}, \mathrm{Fe}$, in antibiotics to cure infections and antioxidants as a deterrent to degenerative diseases (Suharyono and Susilowati, 2006).

Soybean is known as one of the best sources of vegetable proteins with a protein content of $34-44 \%$ (Raghuvansi and Bisht, 2008). Soybean contains the most complete essential amino acids despite possessing a limiting amino acid, which is an amino acid that contains sulfur. The fat content in soybean is $18-20 \%$, and consists mostly of triglycerides, whereas the carbohydrate content of soybean is $25.4-32.5 \%$, consisting of monosaccharides, oligosaccharides, starch and other carbohydrates. Soybean is also a good source of minerals, namely calcium, iron ( $\mathrm{Fe}), \mathrm{Cu}, \mathrm{Zn}, \mathrm{Mg}$, and $\mathrm{Na}$ (Astuti, 2002). Legumes contain phenolic compounds in several forms. Phenolic compounds contained in legumes include hydroxybenzoic acid, hydroxycinnamic acid both free and bound, flavonoids - especially the flavan-3-ols, and flavonols and flavones in the form of glycosides. Some phenolic compounds act as antioxidants, but some others have antinutrient properties (Becker and Siddhuraju, 2006). According to Shahidi and Naczk (2005), phenolic or polyphenolic compounds are natural antioxidants within the flavonoid group, derivatives of cinnamic acid, coumarin, tocopherol, and polyfunctional organic acids Flavonoids with antioxidant activity are flavon, flavonol, Isoflavon, catechin, and chalcone.

On the other hand, legumes can be indicated with aflatoxin during post-harvest and storage processes. Aflatoxins are mycotoxins that often contaminate grains, legumes, and processed products made from seeds and legumes, such as tempeh. Aflatoxin is a secondary 
metabolite compound that is poisonous, produced by certain strains of the moulds Aspergillus flavus and $A$. parasiticus (Klich 2007). Aflatoxin is among the firstclass carcinogens in humans (Bankole et al., 2005), as well as has the reputation of being hepatotoxic, carcinotoxic and teratogenic. Aflatoxin is accumulative and will pose a problem if as many as $1000 \mathrm{ppb}$ of it settle in the liver. Aflatoxin is the potential cause of liver damage, cirrhosis, and liver cancer (Paramawati et al., 2006). Aspergillus flavus produces aflatoxin $\mathrm{B}$, and $A$. parasiticus produces aflatoxins $\mathrm{B}$ and $\mathrm{G}$. Whereas aflatoxin $\mathrm{M}_{1}$ and $\mathrm{M}_{2}$ are metabolites produced by the hydroxylation of aflatoxins $\mathrm{B}_{1}$ and $\mathrm{B}_{2}$ by the cytochrome p450 $1 \mathrm{~A} 2$ in humans or animals that consume aflatoxincontaminated foods (Huang, 2007). According to the International Agency for Research on Cancer (2002), aflatoxin is among the first-class substances, particularly Aflatoxin $B_{1}$ which is a carcinogenic substance in humans. Aflatoxin $\mathrm{B}_{1}$ is the most toxic. In addition to being carcinogenic, this aflatoxin is also genotoxic, hepatoxic in humans, and nephrotoxic and immunosuppressive in animals. The limit of aflatoxin contamination in food is $20 \mathrm{ppb}$ and milk is $0.5 \mathrm{ppb}(\mathrm{Wu}$, 2004). The objective of this research was to determine the antioxidant activity, total phenolic compounds and aflatoxin content in tempeh made from assorted soybeans.

\section{Materials and methods}

\subsection{Plant materials}

The raw materials used are dried local soybeans consisting of a) Anjasmoro, b) Dena 1, and c) Devon, all of which were harvested from the Malang branch of the Research Institute of Various Legumes and Bulbs (Balitkabi) during the dry season and imported soybeans from the United States which were obtained from the Tempeh and Tofu Cooperative in Sanan Village, Malang.

\subsection{Preparation of tempeh}

A total of $100 \mathrm{~g}$ of treated soybean seeds were sorted and washed, given the boiling I treatment (for 30 mins after the water boiled), soaked in water for $24 \mathrm{hrs}$ with the water level of $5 \mathrm{~cm}$ above the soybean seeds, then the husks were peeled and the peeled soybean seeds were given washing II treatment, then boiling II treatment (30 mins after the water boiled) with the ratio of soybean seeds: water $=1: 10 \mathrm{~b} / \mathrm{v}$, after that the seeds were drained and then evenly placed on the "tampah" (tray made of woven bamboo) to undergo the cooling process until the temperature was below $40^{\circ} \mathrm{C}$. The next process was fermentation, in which the soybean seeds were dried from boiling water and then mixed with $0.2 \%$ of tempeh yeast (Rhizopus sp.) by sprinkling the yeast evenly over the soybeans. The soybeans were stirred until the yeast was evenly mixed and then the whole mixture was wrapped in a $250 \mathrm{~g}$ plastic bag which had 15 holes on its top and bottom sides, and 3 holes each on its right and left sides. Alternatively, the mixture was wrapped in banana leaves without the holes. The last stage was the curing/fermentation process for $48 \mathrm{hrs}$ at room temperature $\left(28-30^{\circ} \mathrm{C}\right)$. Prior to analysis, the fresh tempeh was stored at $-20^{\circ} \mathrm{C}$.

\subsection{Antioxidant activity using the DPPH method}

The antioxidant activity of samples was determined using the method developed by Williams et al. (1995). The extraction filtrate was $4 \mathrm{~mL}$, added with $1 \mathrm{~mL}$ of DPPH solution at the concentration of $0.2 \mathrm{~nm}$, allowed to stand for 30 mins, taken as much as $1 \mathrm{~mL}$ and had its absorbance measured at $\lambda 517 \mathrm{~nm}$.

The effects of DPPH capture $(\%)=[(\mathrm{Ao}-\mathrm{A} 1 / \mathrm{Ao})$ $\mathrm{x}$ 100]

Where Ao $=$ absorbance of the control or without the addition of the extract and A1 = absorbance of the sample

\subsection{Total phenolic content}

The total phenol content was measured using a modified Folin-Ciocalteu method in Ahmed et al. (2015). The production of pre-reaction $7 \% \mathrm{Na}_{2} \mathrm{CO}_{3} 3.5 \mathrm{~g}$ $\mathrm{Na}_{2} \mathrm{CO}_{3}$ was measured, dissolved with Aqua Bidestilata to $50 \mathrm{~mL}$ The production of Tempeh extract solution was made by measuring $10 \mathrm{mg}$, dissolved with $10 \mathrm{~mL}$ of methanol. Determination of the total phenol content of tempeh extract was carried out using a UV-VIS spectrophotometry. Each well was pipetted as much as 1 $\mathrm{mL}$ of tempeh extract, and the sample was added with $0.4 \mathrm{~mL}$ of the Folin-Ciocalteau reagent, shaken and allowed to stand for 4-8 mins, added with $4.0 \mathrm{~mL}$ of $7 \%$ $\mathrm{Na}_{2} \mathrm{CO}_{3}$ solution, and was shaken until homogenous. Aquabidestilata was added up to $10 \mathrm{~mL}$ and allowed to stand for $2 \mathrm{hrs}$ at room temperature. The absorbance was measured at a maximum absorption wavelength of 744.8 $\mathrm{nm}$. The levels of the obtained phenol were in $\mathrm{mg}$ equivalent gallic acid/g extract.

\subsection{Aflatoxin contamination}

Aflatoxin contamination tests used the LC-MS/MS method. A mass of $2 \mathrm{~g}$ of the sample was homogenized with $8 \mathrm{~mL}$ of extraction solvent (acetonitrile: water, $80: 20, \mathrm{v} / \mathrm{v}$ ) and shaken for 20 mins. Afterwards, it was centrifuged for $10 \mathrm{mins}$ at $3500 \mathrm{rpm}$ and filtered using Phenomenex Filter PHENEX (RC Membrane $15 \mathrm{~mm}$ $0.45 \mu \mathrm{m})$. The filtrate was then diluted 1:4 with water 
containing $5 \mathrm{mM}$ ammonium acetate and tested for aflatoxin contamination using a Shimadzu Nexera HPLC (Martos et al., 2010). The concentration of aflatoxin content was calculated based on the chromatogram sample area using the following formula:

$$
\begin{gathered}
\text { Ratio/weight }(g)=\frac{\text { AA (area) }}{\text { sample weight }} \\
\text { Alfatoxin Concentration }(p p b)=\frac{\frac{\text { ratio }}{\text { weight }} \text { of material }}{\text { highest value of ratio/weight }} \times 100 \% \times 10^{-7}
\end{gathered}
$$

\section{Results and discussion}

\subsection{Aflatoxin type profile}

The results of the characterization of aflatoxin content using LC-MS/MS on tempeh made from 4 types of soybean (US-imported, local Dena 1, local Devon 1, local Anjasmara) are provided in Figures 1, 2, 3 and 4. Figure $(1,2,3,4) \mathrm{b}$ shows that the ion fragmentation [M$\mathrm{X}]^{+}$is $\mathrm{m} / \mathrm{z} 312$, thus confirming aflatoxin detection of the B1 variant. Figure $(1,2,3,4) \mathrm{c}$ shows that the ion fragmentation $[\mathrm{M}-\mathrm{X}]^{+}$is $\mathrm{m} / \mathrm{x} 258.50$ to 259.50 , and the molecular ion peak $[\mathrm{M}]^{+}$is $\mathrm{m} / \mathrm{z} 315$, thus confirming aflatoxin detection of the B2 variant. Figure $(1,2,3,4) \mathrm{d}$ shows that the ion fragmentation $[\mathrm{M}-\mathrm{X}]^{+}$is $\mathrm{m} / \mathrm{z} 282.50$ to 283.50 , and the molecular ion peak $[\mathrm{M}]^{+}$is $\mathrm{m} / \mathrm{z} 329$, thus confirming aflatoxin detection of the G1 variant, except for Devon 1 wherein the chromatogram peak is irregular/asymmetrical, confirming that tempeh from Devon 1 soybeans did not yield aflatoxin detection of the

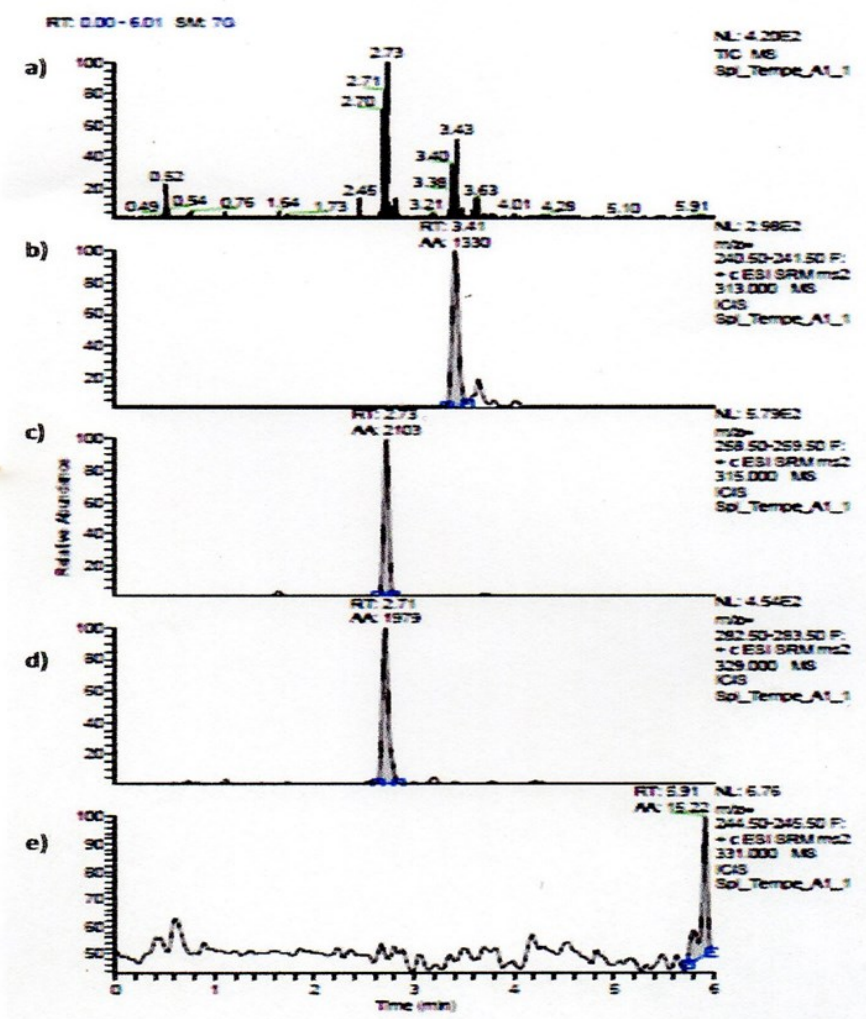

Figure 1. Chromatograms of the types of aflatoxin in tempeh made of US-imported soybean: a) combined, b) B1, c) B2, d) $\mathrm{G} 1$, e) $\mathrm{G} 2$
G1 variant. Whereas Figure $(1,2,3,4)$ e, for G2 aflatoxin, the ion fragmentation $[\mathrm{M}-\mathrm{X}]^{+}$is $\mathrm{m} / \mathrm{z} 244.50$ to 245.50 , and the molecular ion peak $[\mathrm{M}]^{+}$is $\mathrm{m} / \mathrm{z} 331$ and all soybeans have irregular/asymmetrical chromatogram peak; in other words, G2 aflatoxin is not detected. Based on the type profiles of aflatoxins in tempeh made from 4 soybean variants, it can be concluded that tempeh made from US-imported soybeans, Dena 1 and Anjasmara contain aflatoxins of the B1, B2 and G1 variant, while tempeh made from Devon 1 soybean only contain aflatoxins of the $\mathrm{B} 1$ and $\mathrm{B} 2$ variants. Tempeh made from Devon 1 soybeans only contains A1 and A2 aflatoxins. This is thought to be due to certain strains of Aspergillus sp. that can grow well on the ingredients, as well as favourable environmental conditions such as temperature and humidity. Broto (2018) stated that the interaction between the strain genotype and the environment in which Aspergillus sp. grew would determine its aflatoxin production. This is supported by the research results of Pratiwi et al. (2015) which stated that temperature, humidity and growing media greatly affected the growth and production of Aspergillus BIO 2237's aflatoxin. According to Baranyi et al. (2015) of the group and species of Aspergillus sp. the only producers of B1 and B2 aflatoxin were the Flavi groups with sp. A. flavus and Ochraceorosei group with sp. A. ochraceoroceus and $A$. rambellii. Amaike and Keller (2011) stated that based on its morphology Aspergillus flavus was divided into 2 groups, namely group I which consisted of L strains and group II which consisted of S strains. L strain only

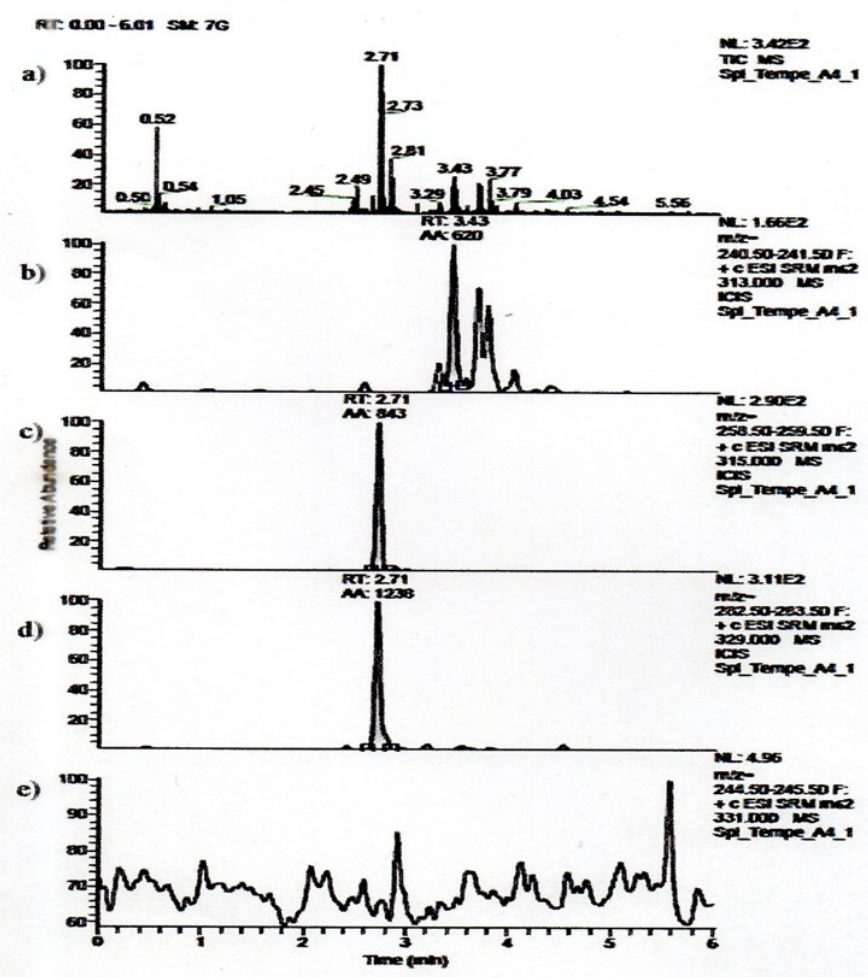

Figure 2. Chromatograms of the types of aflatoxin in tempeh made of "Dena1" local soybean: a) combined, b) B1, c) B2, d) $\mathrm{G} 1, \mathrm{e}) \mathrm{G} 2$ 


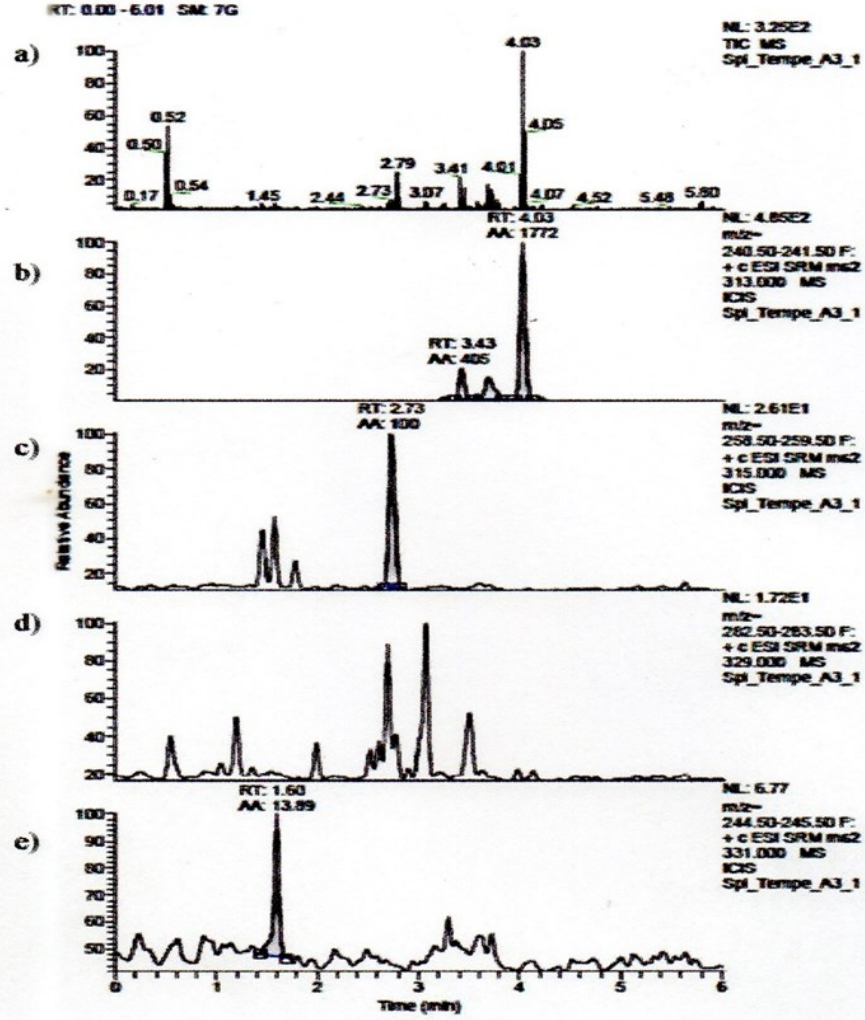

Figure 3. Chromatograms of the types of aflatoxin in tempeh made of "Devon1" local soybean: a) combined, b) B1, c) B2, d) $\mathrm{G} 1, \mathrm{e}) \mathrm{G} 2$

produced $\mathrm{B} 1$ and $\mathrm{B} 2$ aflatoxins; on the other hand, $\mathrm{S}$ strain, in addition to producing B1 and B2 aflatoxins, also produced G1 and/or G2. Furthermore, aflatoxin contamination in tempeh made from imported soybeans from the US is greater than local soybeans because in the process of shipping and distributing the imported soybeans to tempeh producers the time is longer than the possibility of contamination by Aspergilus sp. is greater. Information from a soybean importer PT. Seger Agro Nusantara (SAN) revealed that shipping time from America to Indonesia took approximately 40 days (Prismadani, 2016).

Based on the results of chromatogram area width (Figure 1 to Figure 4), aflatoxin concentration (ppb) can be calculated and the results are provided in Table 1 .

\subsection{Antioxidant activity, total phenolic, and aflatoxin}

The antioxidant activity in tempeh made from local Indonesian soybeans and US-imported soybeans is

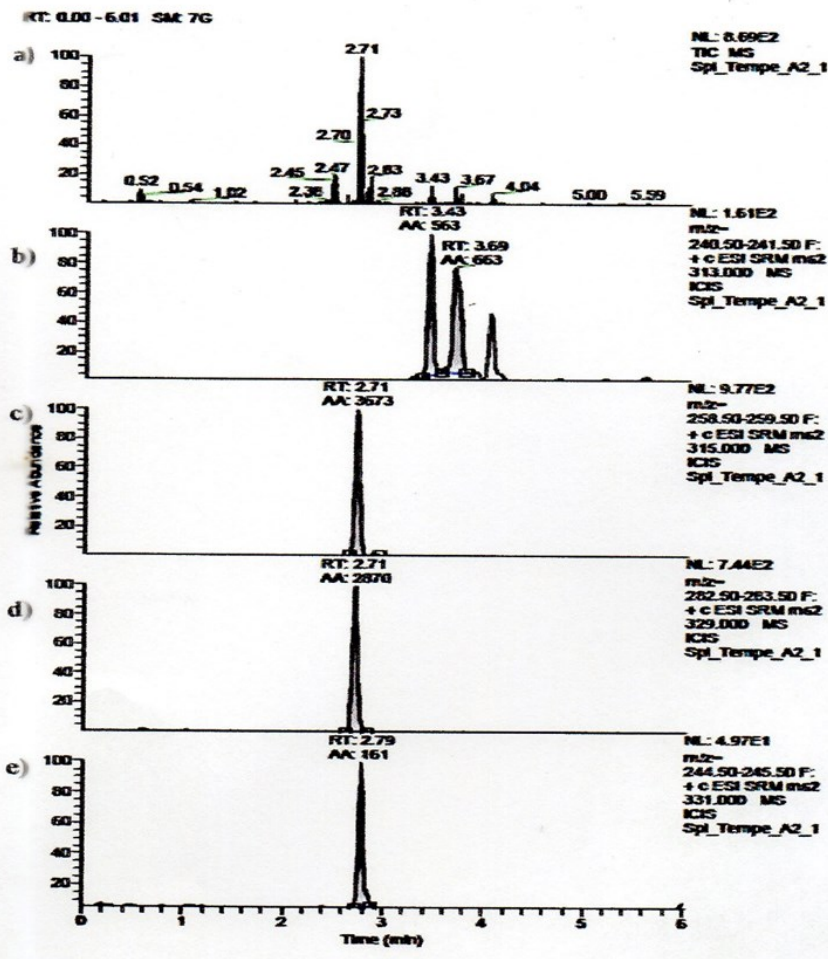

Figure 4. Chromatograms of the types of aflatoxin in tempeh made of " Anjasmoro " local soybean: a) combined, b) B1, c) B2, d) G1, e) G2

provided in Table 1. The table shows that the highest mean of antioxidant activity is found in tempeh made from local Anjasmara variant at $38.62 \pm 0.22 \%$; there are a number of factors, such as genotype, storage period, and cultivation. The results of the study by Yomade et al. (2011) suggests that the antioxidant content, namely polyphenols in rice, was influenced by genotypes. The study by Nurkholidah (2005) suggests that the organic cultivation of garlic by giving it biocontrol could increase the content of antioxidant compounds in the plants. These antioxidants are generally phenolic compounds that are included in the flavonoid group.

Flavonoid is a group of secondary metabolites produced by plants. One important component/bioactive compound found in soybeans that act as an antioxidant is isoflavone (Saija et al., 1995). Soybean isoflavones protect and maintain the health of the body, as well as prevents various diseases. American Dietetic Association (2010) reported that the consumption of natural foods will have a positive effect on health if consumed as a regular diet at effective doses. Indiana Soybean Board

Table 1. Average antioxidant activity (\%), total phenolic (\%), and aflatoxin (ppb) tempeh from various types of soybeans

\begin{tabular}{|c|c|c|c|c|c|c|c|}
\hline \multirow{2}{*}{ No. } & \multirow{2}{*}{ Types of soy } & \multirow{2}{*}{$\begin{array}{c}\text { Antioxidant activity } \\
(\%)\end{array}$} & \multirow{2}{*}{$\begin{array}{c}\text { Total phenolic } \\
\text { (mg GAE/g extract) }\end{array}$} & \multicolumn{4}{|c|}{ Aflatoxin (ppb) } \\
\hline & & & & B1 & B2 & G1 & G2 \\
\hline 1 & US-imported & $30.42 \pm 0.23^{b}$ & $13.99 \pm 0.20^{\mathrm{a}}$ & $1 \times 10^{-5}$ & $1 \times 10^{-5}$ & $7.29 \times 10^{-6}$ & ND \\
\hline 2 & Dena 1 & $29.83 \pm 0.12^{\mathrm{a}}$ & $13.96 \pm 0.29^{\mathrm{a}}$ & $5.14 \times 10^{-6}$ & $1.97 \times 10^{-6}$ & $4.39 \times 10^{-6}$ & ND \\
\hline 3 & Devon 1 & $35.39 \pm 0.47^{\mathrm{c}}$ & $14.24 \pm 0.29^{b}$ & $3.07 \times 10^{-6}$ & $2.53 \times 10^{-7}$ & ND & ND \\
\hline 4 & Anjasmara & $38.62 \pm 0.22^{\mathrm{d}}$ & $16.26 \pm 0.29^{\mathrm{c}}$ & $4.39 \times 10^{-6}$ & $9.33 \times 10^{-6}$ & $1 \times 10^{-5}$ & ND \\
\hline
\end{tabular}

Values are expressed as mean $\pm \mathrm{SD}, \mathrm{n}=3$. Values with the same superscript within the same column are not significantly different $(\mathrm{p}<0.05)$. ND: not detected. 
(1998) recommends consumption of $30-40 \mathrm{mg}$ of isoflavones per day, while Cassidy et al. (1994) maintains that $50 \mathrm{mg}$ of isoflavones per day is sufficient to obtain the desired clinical/biological effects in the body. Furthermore, USDA (2008) stated that the total isoflavone in tempeh was $60.61 \mathrm{mg} / 100 \mathrm{~g}$. Based on this, the findings of this study provide information that consuming $100 \mathrm{~g}$ of tempeh per day has a very positive impact on physical health, especially tempeh made from local Anjasmara soybeans because with the highest antioxidant activity.

Table 1 shows that total phenolic is directly proportional to antioxidant activity. There are several natural compounds that affect antioxidant activity, including total phenol and total flavonoid. Alfianti (2012) reported that high phenolic and flavonoid contents had an antioxidant activity that captured high DPPH radicals in kale plants. Phenol and flavonoid compounds have a linear contribution to antioxidant activity, so the higher their levels, the higher the antioxidants. High total phenolic levels in soybean types have an important role as antioxidants (Ghasemzadeh, 2011). The nature of phenol as an antioxidant is due to its ability to donate hydrogen atoms from hydroxyl to radical compounds so that the radical compounds can be more stable (Prakash, 2001).

In Table 1, the detection of aflatoxin contamination in tempeh using LC-MS/MS yields results for the USimported "Bola" brand soybeans, local Dena 1 and Anjasmara soybeans, where the aflatoxin indication is of the $\mathrm{B}_{1}$ variant; while local Devon 1 soybeans indicate aflatoxin of the $B_{1}$ and $B_{2}$ variants. The highest aflatoxin contamination is found in tempeh made from USimported soybeans, although it is still below the hazard standard set by the BPOM (Food and Drug Monitoring Agency), which is $20 \mathrm{ppb}$ (Farombi, 2006). The European Economic Community determined that the total aflatoxin content is $4.0 \mathrm{ppb}$, in which the $\mathrm{B}_{1}$ variant is $2.0 \mathrm{ppb}$.

\section{Conclusion}

Based on the research results, tempeh with the highest antioxidant activity and total phenolic is made from the local Anjasmara soybean variant, at $38.62 \pm 0.22 \%$ and $16.26 \pm 0.29 \mathrm{mg} \mathrm{GAE} / \mathrm{g}$ extract, respectively. The results of LC-MS/MS tests show that the detected aflatoxin contaminations are from the $\mathrm{B}_{1}$, $B_{2}$, and $G_{1}$ for tempeh made from US-imported soybeans, Dena 1 and Anjasmara, while tempeh made from Devon 1 soybean only contains aflatoxins of the B1 and $B 2$ variants. The $G_{2}$ variant is not detected in tempeh made from all soybean types.

\section{Conflict of interest}

The authors declare no conflict of interest.

\section{References}

Ahmed, S., Ahmad, M.S., Yousaf, M., Mothana, R.A. and Al-Rehaily, A.J. (2015). Evaluation of acute toxicity and anti-inflammatory effects of baccharoides schimperi (DC) in experimental animals. African Journal of Traditional, Complementary and Alternative Medicines, 12(1), 99 -103. https://doi.org/10.4314/ajtcam.v12i1.14

Alfianti, U. (2012). Determination of antioxidant activity in organically and conventionally grown kale (Ipomea reptans Poir)]. Indonesia: Riau University, Thesis.

Amaike, S. and Keller, N.P. (2011). Aspergillus flavus. Annual Review of Phytopathology, 49, 107-133. https://doi.org/10.1146/annurev-phyto-072910095221

American Dietetic Association/ADA Foundation. (2010). Annual report. Retrieved on July 8, 2019 from website: https://www.eatrightpro.org/-/media/eatrightprofiles/about-us/annual\% 20reports/2010_ada_annual_report.pdf? la=en\&hash=E7B87FF6E685B52E84830B7C380F4 EE71F588B16.

Astuti, M. (2002). Functional foods, benefits and prospects for health and the modern food Industry. In Hardini, D. Peroxide number of omega eggs during Processing. Protein Journal UMM Malang, 13(1), 57 $-62$.

Bankole, A., Singh, S. and Trussell, J. (2005). Food and feeding habits of some commercially important fish species in Gbedikere Lake, Bassa Kogi State, Nigeria. International Journal of Lakes and Rivers, 2 (1), 31-36.

Baranyi, N., Kocsube, S. and Varga, J. (2015). Aflatoxins: Climate change and biodegradation. Current Opinion in Food Science, 5, 60-66. https:// doi.org/10.1016/j.cofs.2015.09.002

Becker, K. and Siddhuraju, P. (2006). The Antioxidant and Free Radical Scavenging Activities of Processed Cowpea (Vigna unguiculata (L) Walp.) Seed Extracts. Food Chemistry, 101(1), 10-19. https:// doi.org/10.1016/j.foodchem.2006.01.004

Broto, W. (2018). Contamination status and aflatoxins controlling efforts on cereals and nuts commodities. Journal of Agricultural Research and Development, 37(2), 81-90.

Cassidy, A., Bingham, S. and Setchell, K. (1994). 
Biological effects of isoflavones present in soy in premenopausal women: implications for the prevention of breast cancer. American Journal of Clinical Nutrition, 60(3), 333-340. https:// doi.org/10.1093/ajen/60.3.333

Farombi, E.O. (2006). Review: Aflatoxin contamination of foods in developing countries: Implications for hepatocellular carcinoma and chemopreventive strategies. African Journal of Biotechnology, 5(1), 114.

Ghasemzadeh, A. and Ghasemzadeh, N. (2011). Flavonoids and phenolic acids: Role and biochemical activity in plants and human. Journal of Medicinal Plants Research, 5(31), 6697-6703. https://doi.org/10.5897/JMPR11.363

Huang, J. and Elmashni, D. (2007). Analysis of aflatoxins using fluorescence detection. Thermo Scientific Application Note 381. Retrieved from Thermo Scientific website: http:// tools.thermofisher.com/content/sfs/brochures/AppNote-381-Analysis-of-Aflatoxins-UsingFluorescence-Detection.pdf

IARC. (2002). Some traditional herbal medicines, some mycotoxins, naphthalene and styrene. IARC Monograph on the Evaluation of Carcinogenic Risks to Humans, 82, 1-556.

Indiana Soybean Board. (1998). Isoflavone concentration in soy foods. Retrieved on August 9, 2019 Soyfood website: from www.soyfood.com.nutrition/ isoflavoneconcentration.htmL.

Klich, M.A. (2007). Aspergillus flavus: the major producer of aflatoxin. Molecular Plant Pathology, 8 (6), 713-722. https://doi.org/10.1111/j.13643703.2007.00436.x

Martos, P., Thompson, W. and Diaz, G.J. (2010). Multiresidue mycotoxin analysis in wheat, barley, oats, rye and maize grain by high-performance liquid chromatography-tandem mass spectrometry. World Mycotoxin Journal, 3(3), 205-223. https:// doi.org/10.3920/WMJ2010.1212

Nurkholidah. (2005). Comparison of antioxidant content in organically and conventionally grown salad (Lactuca sativa). Indonesia: Riau University, Thesis.

Paramawati, D.I. and Dummillah, D.D. (2006). Efforts to reduce $B_{1}$ aflatoxin contamination in peanuts with post-harvest technology (case study in Lampung). Jurnal Enjiniring Pertanian, 4(1), 1-8.

Prakash, A. (2001). Antioxidant activity. Medallion Laboratories Analytical Progress, 19, 21-24.

Pratiwi, C., Rahayu, W.P., Lioe, H.N., Herawati, D., Broto, W. and Ambarwati, S. (2015). The effect temperature and relative humidity for Aspergillus
BIO 2237 growth and aflatoxins production on soybeans. International Food Research Journal, 22 (1), 82-87.

Prismadani, N.G. (2016). Determination of the selling price of imported soybeans in the domestic market case study at PT Seger Agro Nusantara. Indonesia: Universitas Sebelas Maret, Thesis.

Raghuvansi, R.S. and Bisht, K. (2008). Uses of soybean: product and preparation. In Singh, G. (ed.). The Soybean: Botany, Production and Uses, p. 404-406. USA: CAB International. https:// doi.org/10.1079/9781845936440.0404

Saija, A., Scalese, M., Lanza, M., Marzullo, D., Bonina, F. and Castelli, F. (1995). Flavonoids as antioxidant agents: importance of their interaction with biomembranes. Free Radical Biology and Medicine, 19(4), 481-486.

Shahidi, F. dan Naczk, M. (2005). Food phenolics. Lancester, United Kingdom: Technomic Pub. Co. Inc.

Suharyono, A.S. and Susilowati. (2006). The Effects of types of tempeh and binding materials on the chemical and organoleptic properties of tempeh nugget products. Proceedings of the Seminar on Research and Community Service Results, p. 280290. Lampung University, Indonesia.

USDA. (2008). USDA Database on the isoflavone of selected foods, release 2.0. Nutrient Data Laboratory. Retrieved from USDA website: https:// www.ars.usda.gov/arsuserfiles/80400525/data/ isoflav/isoflav_r2.pdf

Williams, B.W., Cuvelier, M. and Berset, C. (1995). Use of free radical method to evaluate antioxidant activity. LWT-Food Science and Technology, 28(1), 25-30. https://doi.org/10.1016/S0023-6438(95)80008 $-5$

Wu, F. (2004). Mycotoxin risk assessment for the purpose of setting international regulatory standards. Environmental Science and Technology, 38(15), 4049-4055. https://doi.org/10.1021/es035353n

Yomade, S., Karrila, T. and Pakdeechanuan, P. (2011). Physical, chemical and antioxidant properties of pigmented rice grown in southern Thailand. International Food Research Journal, 18(3), 901906. 